\title{
Land Acquisition for Customary Law Communities: A Review of The Book "Perlindungan Hak atas Tanah Masyarakat Hukum Adat dalam Pengadaan Tanah untuk Kepentingan Umum"
}

Resty Shelya Pujiani

Faculty of Law, Universitas Negeri Semarang

Email: restyshl23@gmail.com

\section{Citation:}

Pujiani, R. S. (2021). Land Acquisition for Customary Law Communities: A Review Of The Book "Perlindungan Hak atas Tanah Masyarakat Hukum Adat dalam Pengadaan Tanah untuk Kepentingan Umum", Lex Scientia Law Review, 5(1), 185-188, doi: https://doi.org/10.15294/lesrev.v5i1.46 903

\section{History of Article}

Received: May 22, 2021

Revised: 17 May, 2021

Accepted: May 25, 2021

(C) The Author(s)

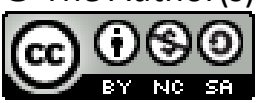

This work is licensed under a Creative Commons Attribution-NonCommercial-ShareAlike 4.0 International License.

All writings published in this journal are personal views of the authors and do not represent the views of this journal and the author's affiliated institutions.

Lex Scientia Law Review published by Faculty of Law, Universitas Negeri Semarang, Indonesia in collaboration of UKM Lex Scientia. Published biannuallyeveryMay and November.

\author{
BOOK DATA \\ Book title \\ : Perlindungan Hak atas \\ Tanah Masyarakat \\ Hukum Adat dalam \\ Pengadaan Tanah untuk \\ Kepentingan Umum \\ Author : Marulak Togatorop \\ Publisher : STPN Press \\ Publication Year : 2020 \\ Publisher City : Yogyakarta \\ Book Language : Indonesia \\ Number of pages : 242 pages \\ Book ISBN $\quad$ : 978-602-7894-18-1

\section{KEYWORDS} \\ Customary Law Community; Land Acquisition; \\ Public Interest
}




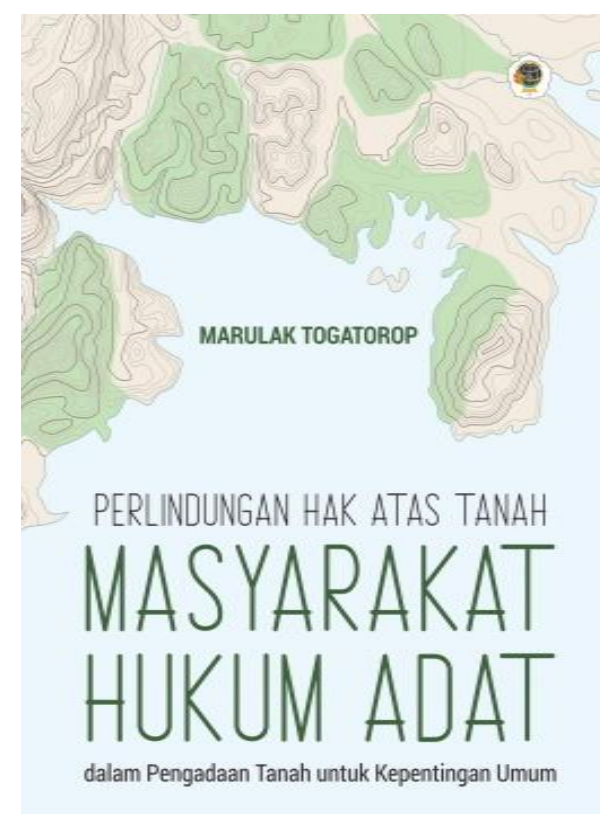

The book, entitled Protection of the Land Rights of Customary Law Communities in Land Acquisition for Public Interest, was written by Marulak Togatorop, which is a work derived from the author's dissertation in the Doctor of Law Program at the Postgraduate Program at Pattimura University in Ambon. This book discusses the rights of Indigenous Peoples to land in land acquisition for public purposes. This book, as a whole, discusses the rights of customary communities to land in land acquisition for public purposes. Land as a type of fixed object that has a very important position in the order of community life. Considering that land has a dual function, there are social function, which means that land owned by a person does not only function for the landowner but also for the Indonesian nation. The use of the land is not only guided by the interests of the right holders, but must also take into account the interests of the community. Therefore, land has a dual function. There are social asset and capital asset.

In the statutory regulations related to the right of the state to limit people's rights to land to accommodate public interests, it is regulated quite clearly in Article 33 paragraph 3 of the 1945 Constitution, which states that "Earth, water and natural resources contained therein are controlled by the state for used for the greatest prosperity of the people ". Then in The Act Number 5 of 1960 concerning Basic Agrarian Principles Article 18 "for the public interest, including the interests of the nation and the state, as well as the common interests of the people, land rights can be revoked by providing appropriate compensation in a manner regulated by law. "Thus, the author of the book explains that there is a state right to regulate land ownership based on public interest.

Although legal arrangements related to land acquisition for public interests have developed from time to time, land acquisition regulations have not accommodated the interests of land rights holders. This is due to land taken under the pretext of public interest, which injures the community, including to the Customary Law Community, because the use of land taken by the government is not as initially planned and even tends to give rise to misery for the community who used to be the right holder. On the pretext of being in the public interest, the rights of indigenous peoples are often taken 
over without any attempt to replace them with other land ownership rights. The need for land to be used by the government for development purposes should not be detrimental to the rights of the landowners, including the rights of the Customary Law Community to land. Thus, there is a need for a legal instrument at the level of law to become a solid legal umbrella to protect the rights of indigenous peoples who are often violated by the state's rights to land.

Land acquisition is providing land by compensating the right and fair losses to the entitled parties. To carry out land acquisition must fulfill several elements; legal actions in relinquishing land rights to state land, relinquishing land rights for public purposes, legal actions based on musyanah are voluntary and just activities, and accompanied by fair and good compensation. The regulations governing land acquisition are The Presidential Decree Number 55 of 1993 Article 1 point 2 "Release or handover of land rights is the activity of releasing the legal relationship between the holder of land rights and the land they control by giving compensation based on deliberation". To guard the above rules, a legal umbrella is needed to protect land owners' rights and ensure that land acquisition runs according to the rules. The National Land Law provides legal protection to land rights holders that the use and control of land by anyone and for anything must be based on land rights provided by the national land law. Legal protection in land acquisition means respect for individual land rights. In connection with the rights of indigenous peoples to certain areas or what is commonly known as Hak Ulayat. The relationship between the customary law community and the land as a unit cannot be separated as a legal partnership. Hak Ulayat is the right of the association to the land that is occupied.

Based on conflicts that have occurred in the community over land rights of customary law communities, such as in the dispute over land rights that occurred in Ambon City, Maluku. This case is a civil case relating to the customary rights of customary communities to land. This conflict happened between the customary law community and a private company over disputed land called Dusun Huurunguang. This conflict occurred because the defendant was not the person entitled to the disputed land, thus causing the community to file a lawsuit in court. Then, the conflict that occurred in East Halmahera Regency, occurred between a mining company that carried out land acquisition by PT. Yudistira Bumi Bakti, PT. Prosperity of Pertiwi Tambang, and PT. Alam Raya Abadi related to the process and compensation based on the regent's decision regarding the price of land and plants for development for the public interest. The description above shows that the 
dominant conflict occurred due to a mismatch in the provision of compensation for community land. Companies and the government tend to view the land from the people's point of view without considering the value of the land, causing compensation to be given based on economical prices alone. As a result, apart from losing their land rights, they also received improper compensation. Conflict resolution can be done through conflict management. Conflict management is needed to build and develop conflict resolution mechanisms to prevent the development of conflict into violence, socially, economically, and ecologically destructive and turn them into constructive and cooperative social relationships.

Implementation of protection of the rights of indigenous peoples to land in procurement for the public interest is stated in Article 18B paragraph 2 "The state recognizes and respects indigenous peoples and their traditional rights as long as they are alive and under community development and the principles of the Unitary State of the Republic of Indonesia. " And Article 28 I paragraph 3 "cultural identity and rights of traditional communities are respected in accordance with the times and civilization." Implementation of protection of the rights of indigenous peoples to land in procurement for the public interest is stated in Article 18B paragraph 2 "The state recognizes and respects indigenous peoples and their traditional rights as long as they are alive and under community development and the principles of the Unitary State of the Republic of Indonesia. " And Article 28 I paragraph 3 "cultural identity and rights of traditional communities are respected under the times and civilization." Implementation of protection of the rights of indigenous peoples to land in procurement for the public interest is stated in Article 18B paragraph 2 "The state recognizes and respects indigenous peoples and their traditional rights as long as they are alive and under community development and the principles of the Unitary State of the Republic of Indonesia. " And Article 28 I paragraph 3 "cultural identity and rights of traditional communities are respected under the times and civilization."

The book, entitled Protection of the Land Rights of Customary Law Communities in Land Acquisition for Public Interest, is compiled in language that is easy to understand. It is relevant to be used as a reference for both students and lecturers. This book also provides a comprehensive and systematic explanation of the rule of law, customary law communities, and land acquisition to protect the customary rights of indigenous peoples. On the other hand, this book is also equipped with conflicts over customary rights between indigenous peoples and certain parties, which are directly sourced from court decision data. The data listed is concrete and should be trusted. 